ROCZNIKI TEOLOGICZNE

Tom LXVI, zeszyt 1 - 2019

DOI:http://dx.doi.org/10.18290/rt.2019.66.1-11

MIKOŁAJ OLSZEWSKI

\title{
MIESZKANIA WSPOMAGANE DLA OSÓB Z NIEPEŁNOSPRAWNOŚCIA W PROCESIE DEINSTYTUCJONALIZACJI
}

\section{ASSISTED LIVING FACILITIES FOR PEOPLE WITH DISABILITIES IN THE PROCESS OF DEISTITUTIONALISATION}

\begin{abstract}
A b s t r a c t. The aim of this article is to present the role of the assisted living facilities in the process of deinstitutionalisation. The analysis referred to international and national documents as well as examples of good practices in creating and running assisted living facilities for people with disabilities. In the end, the author presented a recommendations and a conclusions concerning assisted living facilities.
\end{abstract}

Key words: people with disabilities; assisted living facilities; deinstitutionalisation; social services.

Polska, mimo zapowiedzi, wciąż nie ma opracowanej strategii deinstytucjonalizacji, niemniej jednak od kilku lat można obserwować różne inicjatywy promujące ideę odchodzenia od opieki instytucjonalnej na rzecz opieki środowiskowej w procesie deinstytucjonalizacji. Jednym z elementów tego procesu jest funkcjonowanie mieszkań wspomaganych, które dają możliwość m.in. osobom z niepełnosprawnościami prowadzenia niezależnego życia w społeczności lokalnej, przy wykorzystaniu usług asystenckich.

Dr MikoŁaj OlszewsKi - Wydział Filologiczno-Pedagogiczny, Uniwersytet Technologiczno-Humanistyczny im. Kazimierza Pułaskiego w Radomiu; adres do korespondencji: e-mail: m.olszewski@uthrad.pl; ORCID 0000-0003-1858-8669. 
Celem niniejszego artykułu jest omówienie procesu deinstytucjonalizacji oraz roli mieszkań wspomaganych wraz z odniesieniem się do dokumentów strategicznych oraz aktów prawnych międzynarodowych oraz krajowych. Poddane analizie zostały strategie: Europa 2020, unijna strategia w sprawie niepełnosprawności 2010-2020, Konwencja o Prawach Osób Niepełnosprawnych ONZ oraz krajowa Strategia Odpowiedzialnego Rozwoju, a także wynikające $\mathrm{z}$ nich zalecenia oraz zobowiązania. Przedstawiona zostanie również rola mieszkań wspomaganych (Stargard), mieszkań chronionych (Płock) oraz mieszkań treningowych przy DPS (Konary) utworzonych i prowadzonych przez organizacje pozarządowe, samorządy przy wykorzystaniu funduszy unijnych, funduszy szwajcarskich oraz środków publicznych. Ponadto zaprezentowane zostaną dwa przykłady dobrych praktyk w zakresie mieszkalnictwa wspomaganego mieszanego z Francji (Arras oraz Lille), spełniające wymogi Konwencji o prawach osób niepełnosprawnych ONZ. Metodą wykorzystaną w artykule jest analiza źródeł wtórnych: strategii, aktów prawnych, a także przegląd literatury przedmiotu oraz omówienie wybranych przez autora dobrych praktyk z kraju i zagranicy. W podsumowaniu przedstawione zostały wnioski oraz rekomendacje warunkujące rozwój różnych form mieszkalnictwa wspomaganego $\mathrm{w}$ procesie deinstytucjonalizacji.

\section{PROCES DEINSTYTUCJONALIZACJI A MIESZKANIA WSPOMAGANE}

Identyfikacja negatywnych cech, typowych dla dużych placówek opiekuńczo-bytowych w krajach Europy Zachodniej (od drugiej połowy XX wieku), przyczyniła się do rozwoju i wdrażania procesu deinstytucjonalizacji usług społecznych, który polega na odchodzeniu od opieki instytucjonalnej na rzecz usług świadczonych w społeczności lokalnej. Przy czym proces ten wymaga z jednej strony rozwoju usług świadczonych w lokalnej społeczności, z drugiej - stopniowego ograniczania usług $w$ ramach opieki instytucjonalnej. Celem tego procesu jest zapewnienie osobom niesamodzielnym (m.in. z niepełnosprawnością) godnego traktowania, lepszego dopasowania usług do ich indywidualnych potrzeb oraz umożliwienia im pełniejszego uczestnictwa w życiu społecznym. Warto jednak przypomnieć, iż jeszcze w ubiegłym wieku w przypadku osób z niepełnosprawnością (zwłaszcza intelektualną), w różnym wieku, w sytuacji braku możliwości sprawowania opieki przez rodziców/rodzinę jedyną alternatywą były Domy Pomocy Społecznej. Dominację opieki instytucjonalnej nad środowiskową potwierdzają dane - w 2014 r. roczna alokacja na utrzymanie DPS-ów dla osób nie- 
pełnosprawnych wyniosła $1,8 \mathrm{mld}$ zł, natomiast tylko ok. $700 \mathrm{mln}$ zł przekazano na finansowanie usług opiekuńczych i ośrodków wsparcia ${ }^{1}$. DPS w ostatnim ćwierćwieczu zostały mocno przeobrażone, osiagnnięto duży stopień profesjonalizacji oferowanych usług ukierunkowanych na realizację potrzeb mieszkańców, a także stworzono w nich bezpieczne, intymne, prywatne środowisko zamieszkania $^{2}$. Niemniej jednak, jako placówki opieki całodobowej, nadal mają negatywne cechy ,instytucji”, w której mieszkańcy są odizolowani od ogółu społeczności i/lub zmuszeni mieszkać razem. Jednocześnie osoby te nie posiadają wystarczającej kontroli nad własnym życiem lub nad dotyczącymi ich decyzjami, zaś wymagania organizacyjne mają zazwyczaj pierwszeństwo przed ich indywidualnymi potrzebami ${ }^{3}$.

Prowadzenie działań zmierzających do deinstytucjonalizacji usług opiekuńczych wynika z dokumentów międzynarodowych oraz krajowych. W pierwszym z nich - Europejskiej strategii w sprawie niepełnosprawności 2010-2020 - głównym celem było ułatwienie osobom niepełnosprawnym aktywnego udziału we wszystkich dziedzinach życia w UE, zaś Komisja Europejska (KE) zobowiązała się do wykorzystania funduszy strukturalnych promujących działania skutkujące przechodzeniem od instytucjonalnych do środowiskowych systemów opieki ${ }^{4}$.

W kolejnym dokumencie - strategii Europa 2020 - we wprowadzeniu odwołano się w art. 26 Karty praw podstawowych UE, odnoszącego się do praw osób z niepełnosprawnościami do samodzielności, integracji społecznej i zawodowej oraz udziału w życiu społecznym, jak również podjęte zostały zobowiązania związane z wdrażaniem Konwencji ONZ o prawach osób z niepełnosprawnościami (KoPON). W rezultacie w budżecie na lata 2014-2020 KE dostrzegła, zatwierdziła i uruchomiła środki na deinstytucjonalizację opieki oraz usług opiekuńczych w 12 państwach członkowskich $\mathrm{UE}^{5}$, zaś w 5 państwach umowy o part-

\footnotetext{
${ }^{1}$ Strategia na rzecz Odpowiedzialnego Rozwoju, Ministerstwo Rozwoju, Warszawa 2017, s. 155.

${ }^{2}$ Por. N. Marciniak-Madejska, R. StenKa, K. Weiner, Rozwiazywanie problemu bezdomności $i$ wykluczenia mieszkaniowego $w$ oparciu o ustugi świadczone $w$ lokalnej spoteczności, ROPS Poznań 2015, s. 8 oraz s. 58.

${ }^{3}$ The Common European Guidelines on the transition from institutional to communitybased care, European Expert Group on the Transition from Institutional to Community-based Care, Bruksela 2012, s. 25, www.esn-eu.org/raw.php?page=files\&id=334 (dostęp 27.08.2018).

${ }^{4}$ European Disability Strategy 2010-2020: A Renewed Commitment to a Barrier-Free Europe, COM(2010) 636 final, s. 4-6.

${ }^{5}$ Wśród dwunastu krajów wymienić należy: Bułgarię, Chorwację, Czechy, Estonię, Grecję, Litwę, Łotwę, Polskę, Rumunię, Słowację, Słowenię oraz Węgry, zob. From institutions to community living. Part I: Commitments and structures, European Union Agency for Fundamental
} 
nerstwie zawierające zobowiązanie do deinstytucjonalizacji ${ }^{6}$ i określenia środków wspierających ten proces. Ponadto w 17 państwach członkowskich realizowane są strategie dotyczące deinstytucjonalizacji oraz strategie na rzecz osób z niepełnosprawnościami ${ }^{7}$. Nawiązując zaś do przepisów KoPON, do art. 19 - osoby z niepełnosprawnością mają prawo do wyboru miejsca zamieszkania oraz wyboru gdzie i z kim będą mieszkać, a także dostęp do szerokiego zakresu usług wspierających funkcjonowanie tychże osób w środowisku lokalnym oraz dostęp do indywidualnej opieki koniecznej do życia i integracji w społeczności lokalnej.

Podkreślić należy, iż w ostatnich latach diagnozowano wadliwe rozwiązania prawne (ustawa o pomocy społecznej oraz rozporządzenia wykonawcze), które nie pozwalały na korzystanie $\mathrm{z}$ alternatywnych pozainstytucjonalnych form zamieszkiwania osób z niepełnosprawnością ${ }^{8}$. Podkreślano także różnice w finansowaniu oraz nadzorze nad rodzinnymi domami pomocy a mieszkaniami chronionymi. Brak gwarancji stałego finansowania mieszkań chronionych został zidentyfikowany jako bariera w tworzeniu ich przez gminy ${ }^{9}$. Krytyczne uwagi dotyczące regulacji prawnych, wspierających niezależne życie, wyrażają również środowiska osób z niepełnosprawnością - w Społecznym Raporcie Alternatywnym z realizacji Konwencji o prawach osób z niepełnosprawnościami w Polsce, wskazując m.in. na: rozproszenie kompetencji; mechanizm przyznawania świadczeń niepieniężnych skonstruowany niekorzystnie dla rodzin z osobą z niepełnosprawnością; ograniczony dostęp do usług opiekuńczych oraz specjalistycznych usług opiekuńczych świadczonych w miejscu zamieszkania zarówno w domu jak również w placówce (ŚDS, mieszkanie chronione, RDP czy pobyt w DPS); brak placówek okresowego pobytu w przypadku

Rights, Luksemburg 2017, s. 10, http://fra.europa.eu/sites/default/files/fra_uploads/fra-2017independent-living-part-i-commitments-structures_en.pdf (dostęp 29.08.2018).

${ }^{6} \mathrm{~W}$ tym przypadku są to: Dania, Irlandia, Malta, Portugalia i Hiszpania, From institutions, s. 10.

7 Tamże, s. 11-14, niestety wciąż nie jest gotowa strategia na rzecz osób z niepełnosprawnościami w Polsce, obecnie trwają prace nad Strategią na rzecz Osób Niepełnosprawnych na lata 2018-2030, zob. szerzej: https://www.mpips.gov.pl/aktualnosciwszystkie/art, 5528,10205, sprawozdanie-z-wykonywania-konwencji-o-prawach-osob-niepelnosprawnych-.html (dostęp 10.09.2018).

${ }^{8}$ Zob. szerzej: A. DudzIŃSKA, A. SoBCZAK, Potrzeby i oczekiwania osób z różnymi niepetnosprawnościami dotyczace przyszłej sytuacji mieszkaniowej, w: Niezależne życie i petne uczestnictwo osób niepetnosprawnych w życiu spotecznym, red. A. Sobczak, Wydawnictwo Uniwersytetu Łódzkiego, Łódź 2012, s. 65-78.

${ }^{9}$ Realizacja przez Polske zobowiazań wynikajacych z Konwencji o prawach osób niepetnosprawnych, Sprawozdanie Rzecznika Praw Obywatelskich, Biuro Rzecznika Praw Obywatelskich, Warszawa 2015, s. 50-51, https://www.rpo.gov.pl/sites/default/files/Sprawozdanie\%2 0KPON\%202015.pdf (dostęp 28.12.2018). 
hospitalizacji opiekuna osób z niepełnoprawnością. Jak zauważają autorzy raportu, w Polsce powstaje bardzo niewiele mieszkań chronionych i innych małych form grupowego zamieszkania w środowisku lokalnym, w formule rodzinnych domów pomocy albo małych domów pomocy społecznej. Jeśli takie pojedyncze placówki powstają z inicjatywy organizacji pozarządowych lub grup rodziców, to samorządy finansują je w bardzo ograniczonym stopniu lub odmawiają finansowania ${ }^{10}$. W zaktualizowanym w 2017 r. Społecznym Raporcie Alternatywnym podkreślono, iż mieszkania chronione nadal nie są zgodne z art. 19 KoPON, gdyż wykluczają osoby potrzebujące całodobowego wsparcia i nie przeciwdziałaja gettoizacji. Ponadto brak jest rzetelnych danych o instytucjach oraz formach wsparcia na poziomie społeczności lokalnych - np. nie można ustalić rodzaju niepełnosprawności lub powodu umieszczenia osób w placówkach ${ }^{11}$.

Natomiast w dokumencie rządowym - w krajowej Strategii Odpowiedzialnego Rozwoju, przyjętej w lutym 2017 r., założono m.in. wsparcie deinstytucjonalizacji opieki nad osobami niesamodzielnymi, możliwie szeroki rozwój usług środowiskowych (opiekuńczych oraz asystenckich), a także wsparcie rodziny i opiekunów faktycznych w pełnieniu ich roli opiekuńczo-wychowawczej. Ponadto, założono stopniowe ograniczanie udziału osób przebywających w placówkach zamkniętych na rzecz zwiększania udziału wsparcia środowiskowego, co niekoniecznie oznacza ograniczanie liczby miejsc w samych instytucjach opiekuńczych. $\mathrm{Z}$ jednej strony umożliwi to aktywizację osób w wieku aktywności zawodowej, obciążonych dziś obowiązkami opiekuńczymi nad osobami z niepełnosprawnością (w różnym wieku), z drugiej zaś może sprzyjać podjęciu aktywności zawodowej przez osoby z niepełnosprawnościami ${ }^{12}$. Przyszłość pokaże, na ile powyższe założenia przełożą się na konkretne rozwiązania promujące niezależne życie osób z niepełnosprawnościami w społeczności lokalnej.

Środki finansowe $\mathrm{z}$ EFS, dostępne zarówno w ramach POWER oraz 16 RPO, umożliwiają tworzenie mieszkań wspomaganych przez samorządy oraz NGO's. Ponadto w ramach programów wspólnotowych opracowywane są standardy, czego przykładem może być projekt konkursowy POWER \{Nie\}Samo-

\footnotetext{
${ }^{10}$ Spoteczny Raport Alternatywny z realizacji Konwencji o prawach osób z niepetnosprawnościami w Polsce, Warszawa 2015, s. 32 http://konwencja.org/download/spoleczny-raport-al ternatywny-doc/\# (dostęp 28.12.2018).

11 Aktualizacja Społecznego Raportu Alternatywnego z realizacji Konwencji o prawach osób z niepełnosprawnościami w Polsce, s. 6-7, http://konwencja.org/download/aktualizacjaspolecznego-raportu-alternatywnego-pdf/\# (dostęp 28.12.2018).

12 Strategia na rzecz Odpowiedzialnego Rozwoju, s. 163.
} 
dzielni, pn. Wypracowanie standardów i przeprowadzenie pilotaży w zakresie usług mieszkalnictwa wspomaganego dla osób o specyficznych potrzebach, z uwzględnieniem możliwości finansowania tych rozwiązań.

Wypracowanie powyższych standardów jest istotne, gdyż - jak podkreśla K. Roszewska - mieszkania wspomagane nie są korzystnym rozwiązaniem dla wszystkich osób z niepełnosprawnościami. Jej zdaniem w przypadku osób nisko funkcjonujących $\mathrm{z}$ autyzmem, nie komunikujących się werbalnie i mających trudności w ocenie sytuacji społecznych, rodzi się ryzyko pełnej zależności pomiędzy wspierającym a osobą całkowicie od niego zależną. Dlatego też postulują małe domy (10-12 osób) dla autystów, z wieloosobową kadrą, gdyż w przypadku odejścia jednego czy dwóch pracowników, pozostają w domu osoby dobrze znane osobie $\mathrm{z}$ autyzmem (kadra oraz współmieszkańcy) ${ }^{13}$.

Biorąc pod uwagę znaczenie mieszkań wspomaganych dla osób z niepełnosprawnościami w procesie deinstytucjonalizacji można odwołać się do następujących zasad, których realizację umożliwiają mieszkania wspomagane:

- autonomii - rozumianej jako zdolność do podejmowania decyzji samodzielnie i wprowadzania ich w życie;

- niezależności - poprzez odejście do familializacji opieki;

- równości - polegającej na dostępności do środowiska społecznego, kulturalnego, mieszkań, transportu, usług społecznych, ale także szans kształcenia oraz pracy ${ }^{14}$;

- normalizacji - poprzez stworzenie im warunków życia codziennego i wzorców funkcjonowania społecznego takich samych lub możliwie najbardziej zbliżonych do norm i wzorców obowiązujących w głównym nurcie społecznym ${ }^{15}$;

- empowermentu - wzmacnianie podmiotowości rozumiane jako samosterowność, zdolność do dokonywania wyborów, do działania, odpowiedzialności i kierowania własnym życiem ${ }^{16}$.

13 Zob. P. KUBICKI, Polityka publiczna wobec osób z niepetnosprawnościami, Oficyna Wydawnicza SGH, Warszawa 2017, s. 148-150.

${ }^{14}$ Por. M.A. PASZKOwICZ (red.), Ćwierć wieku systemu rehabilitacji spotecznej $i$ zawodowej osób z niepetnosprawnościami w Polsce - wybrane aspekty, w: Osoby z niepetnosprawnościami $w$ polityce spotecznej, t. 2. 25-lecie systemu rehabilitacji zawodowej i społecznej w Polsce, Wydawnictwo Uniwersytetu Zielonogórskiego, Zielona Góra 2017, s. 29 oraz P. KUBICKI, Polityka publiczna, s. 63-65.

${ }^{15}$ N. MarciniaK-Madejska, R. StenKa, K. Weiner, Rozwiazywanie problemu, s. 15.

${ }^{16}$ D. PODGÓRSKA-JACHNIK, Praca socjalna z osobami z niepetnosprawnościq i ich rodzinami, Centrum Rozwoju Zasobów Ludzkich, Warszawa 2014, s. 34. 


\section{MIESZKANIA WSPOMAGANE - KWESTIE DEFINICYJNE ORAZ ZAKRES WSPARCIA}

W przypadku działających w Polsce mieszkań wspomaganych należy wymienić mieszkania chronione, które są jedyną formą zdefiniowaną i usankcjonowaną prawnie (art. 53 Ustawy o pomocy społecznej z 12 marca 2004 r.).

Ponadto wymienić należy mieszkania wspomagane, które zgodnie z definicja zawartą w wytycznych opracowanych przez Ministerstwo Finansów i Rozwoju w 2014 r. są usługą społeczną świadczoną w społeczności lokalnej ${ }^{17}$.

Mieszkania chronione (treningowe oraz wspierane) są formą pomocy społecznej, w ramach której pełnoletnie ${ }^{18}$ osoby, które ze względu na trudną sytuację życiową, wiek, niepełnosprawność lub chorobę otrzymują wsparcie specjalistów, mieszkania do prowadzenia samodzielnego życia oraz wsparcie w codziennym funkcjonowaniu. Mieszkania chronione w świetle ustawy oferowane są osobom, które nie wymagają całodobowej opieki, tym samym nie stanowią realnej alternatywy dla DPS, a takie możliwości dają mieszkania wspomagane w Stargardzie czy też w Warszawie.

W zależności od celu udzielanego wsparcia usankcjonowany został podział na mieszkania chronione treningowe ${ }^{19}$ lub mieszkania chronione wspiera$\mathrm{ne}^{20}$ (art. 53 ust. 2 UoPS). Zgodnie $\mathrm{z}$ art. 36 UoPS pobyt $\mathrm{w}$ mieszkaniu

\footnotetext{
${ }^{17}$ Wytyczne $w$ zakresie realizacji przedsięwzięć $w$ obszarze wtaczenia spotecznego i zwalczania ubóstwa z wykorzystaniem środków Europejskiego Funduszu Spotecznego i Europejskiego Funduszu Rozwoju Regionalnego na lata 2014-2020, Ministerstwo Finansów i Rozwoju, Warszawa 2014, s. 7-8.

${ }^{18}$ Wprowadzenie kryterium wieku było przedmiotem krytyki ze strony organizacji prowadzących mieszkania chronione dla młodszych, gdyż wyklucza to możliwość odbywania krótkich treningów, np. w okresie weekendu czy wakacji, por. M. DĄBEK, „Za życiem” pod lupq: komu mieszkania chronione? http://www. niepelnosprawni.pl/ledge/x/576278 (dostęp 15.04.2018). Na istotę zamieszkiwania poza rodziną przez osoby $\mathrm{z}$ niepełnosprawnością $\mathrm{w}$ okresie dorastania wskazuje N. Marciniak-Madejska, por. Mieszkalnictwo wspomagane dla osób z niepetnosprawnościa intelektualna, „Niepełnosprawność i Rehabilitacja” 1(2014), s. 103-105.

${ }^{19} \mathrm{~W}$ minimalnym standardzie usług $\mathrm{w}$ mieszkaniu chronionym treningowym wymienione zostały usługi polegające na nauce, rozwijaniu lub utrwalaniu umiejętności w zakresie: samoobsługi; zaspokajania codziennych potrzeb życiowych; efektywnego zarządzania czasem; prowadzenia gospodarstwa domowego; załatwiania spraw urzędowych; utrzymywania więzi rodzinnych; uczestniczenia w życiu społeczności lokalnej oraz poszukiwania pracy, zob. §3 rozporządzenia w sprawie mieszkań chronionych Ministra Rodziny, Pracy i Polityki Społecznej z dnia 28 kwietnia $2018 \mathrm{r}$.

${ }^{20} \mathrm{~W}$ minimalnym standardzie usług w mieszkaniu chronionym wspieranym wymienione zostały usługi obejmujące pomoc w wykonywaniu czynności niezbędnych w życiu codziennym związanych z: przemieszczaniem się; utrzymaniem higieny osobistej; ubieraniem się; sprząta-
} 
chronionym jest świadczeniem niepieniężnym, dostępnym w ramach systemu pomocy społecznej. Mieszkania wspierane, podobnie jak mieszkania treningowe, sa przyznawane na czas określony jedynie osobom o znacznym lub umiarkowanym stopniu niepełnosprawności, a w szczególnie uzasadnionych przypadkach także innym osobom może być wydana decyzja o skierowaniu do korzystania ze wsparcia w mieszkaniu chronionym wspieranym na czas nieokreślony. Decyzja o przyznaniu wsparcia w przypadku mieszkań chronionych, prowadzonych przez JST lub też na ich zlecenie, odbywa się na podstawie decyzji administracyjnej w oparciu o uzgodnienia w formie pisemnej

Tabela 1. Mieszkania wspomagane w procesie rehabilitacji społecznej

\begin{tabular}{|c|c|c|}
\hline & Mieszkanie treningowe & Mieszkanie docelowe \\
\hline Rodzaj & $\begin{array}{l}\text { mieszkanie jedno- lub dwuoso- } \\
\text { bowe }\end{array}$ & $\begin{array}{l}\text { mieszkanie indywidualne, dwu- } \\
\text { osobowe lub grupowe }\end{array}$ \\
\hline Czas pobytu & określony & nieokreślony \\
\hline Cel & edukacja i rehabilitacja & integracja społeczna \\
\hline \multirow{2}{*}{ Zakres wsparcia } & $\begin{array}{l}\text { całodobowe wsparcie asystenta } \\
\text { w oparciu o indywidualne po- } \\
\text { trzeby }\end{array}$ & $\begin{array}{l}\text { wsparcie asystenta według indy- } \\
\text { widualnych potrzeb mieszkańca }\end{array}$ \\
\hline & $\begin{array}{l}\text { program terapeutyczny opraco- } \\
\text { wany przez terapeutę }\end{array}$ & $\begin{array}{l}\text { brak odgórnych wytycznych co do } \\
\text { terapii, cele określa osoba z nie- } \\
\text { pełnosprawnością }\end{array}$ \\
\hline
\end{tabular}

Źródło: Opracowanie własne na podstawie: N. MARCINIAK-MADEJSKA, Mieszkalnictwo wspomagane dla osób z niepetnosprawnościa intelektualna, „Niepełnosprawność i Rehabilitacja” 1(2014), s. 107.

pomiędzy pracownikiem socjalnym a osobą z niepełnosprawnością lub jej przedstawicielem ustawowym. Wysokość odpłatności zależna jest od kryterium dochodowego. W uzasadnionych przypadkach możliwe jest zwolnienie z odpłatności.

Mając na uwadze rolę mieszkań treningowych i wspomaganych w procesie rehabilitacji społecznej, należy podkreślić wyraźny podział na mieszkanie treningowe i docelowe.

niem; zakupami i przygotowywaniem posiłków; załatwianiem spraw osobistych. Ponadto w standardzie wymieniono pomoc w realizacji kontaktów społecznych przez umożliwienie osobie: utrzymywania więzi rodzinnych oraz uczestnictwa w życiu społeczności lokalnej, zob. $\S 4$ rozporządzenia w sprawie mieszkań chronionych Ministra Rodziny, Pracy i Polityki Społecznej z dnia 28 kwietnia 2018 r. 
W praktyce mieszkania chronione najczęściej są formą czasowego wsparcia, zaś mieszkania wspomagane, np. funkcjonujące w ramach modelu stargardzkiego, czy mieszkania dla osób z niepełnosprawnością oraz osób starszych, są mieszkaniami docelowymi, będącymi alternatywną dla DPS formą zamieszkania w środowisku lokalnym ${ }^{21}$.

Możliwości tworzenia oraz finansowania pobytu oraz usług w mieszkaniach treningowych oraz docelowych stwarzaja także środki unijne. Jak wspomniano we wstępie do niniejszego punktu mieszkania wspomagane, które - zgodnie $\mathrm{z}$ definicja zawartą $\mathrm{w}$ wytycznych opracowanych przez MFiR w 2014 r. - są usługą społeczną świadczoną w społeczności lokalnej w postaci mieszkania lub domu przygotowującego osoby w nim przebywające, pod opieką specjalistów, do prowadzenia samodzielnego życia lub zapewniającego pomoc w prowadzeniu samodzielnego życia. Mieszkanie lub dom mogą być prowadzone $\mathrm{w}$ formie:

- mieszkania treningowego na czas określony, służącego odzyskaniu częściowej lub całkowitej samodzielności, m.in. poprzez trening samodzielności, poradnictwo, pracę socjalną lub inne usługi aktywnej integracji;

- mieszkania wspieranego, na pobyt okresowy bądź stały (docelowy) dla osób niesamodzielnych i osób $\mathrm{z}$ niepełnosprawnościami, wymagających wsparcia w formie usług opiekuńczych lub asystenckich.

W kolejnym punkcie przedstawione zostaną przykłady dobrych praktyk w zakresie mieszkań wspomaganych oraz mieszkań chronionych, funkcjonujących w społeczności lokalnej, jak również działających przy Domu Pomocy Społecznej.

\section{PRZYKŁADY DOBRYCH PRAKTYK MIESZKAŃ WSPOMAGANYCH ORAZ MIESZKAŃ TRENINGOWYCH}

\section{Mieszkania wspomagane o charakterze docelowym - Stargard}

Mieszkania wspomagane w Stargardzie działają od 1999 r. dzięki realizowanej oddolnie współpracy z samorządem i Stargardzkim Towarzystwem Budownictwa

\footnotetext{
${ }^{21}$ Zob. szerzej na temat mieszkań na pobyt czasowy oraz mieszkań docelowych dla osób z niepełnosprawnością: N. MARCINIAK-MADEJSKA, Mieszkalnictwo wspomagane, s. 107-111, J. KRZYSZKowsKi, A. ŁUKOMSKA-DULAJ, A. MiśKOWIEC i in., Utworzenie i funkcjonowanie modelowego przyktadu mieszkania chronionego oraz lokalu aktywizujacego, Ministerstwo Zdrowia, Warszawa 2017, s. 15, 19; R. NECEL, M. ZARĘBA, Ustugi społeczne - między teoria a praktyka działań pomocowych, „Praca Socjalna” 1(2017), s. 49.
} 
Społecznego (STBS) ${ }^{22}$ oraz działaniom dwóch NGO's: stargardzkiego koła Polskiego Stowarzyszenia na Rzecz Osób z Upośledzeniem Umysłowym (PSOUU) oraz Stowarzyszenia Osób Niepełnosprawnych Ruchowo i Przyjaciół „Pomost”. W programie „Potrzebny dom”, będącym owocem współpracy wyżej wymienionych podmiotów, powstały 22 mieszkania wspomagane dla osób niepełnosprawnych ruchowo oraz 35 mieszkań wspomaganych dla osób niepełnosprawnych intelektualnie ${ }^{23}$. Mieszkania wspomagane udostępniane są najemcom bezterminowo, podpisywana jest umowa najmu lokalu, który staje się lokalem docelowym. Lokale są pojedyncze, umeblowane przez lokatora, ze wspólną dla trzech mieszkań jadalnią z aneksem kuchennym.

Korzyści ekonomiczne, wynikające z procesu deinstytucjonalizacji opieki oraz z programu mieszkań wspomaganych w Stargardzie, przedstawia tabela 2.

Tabela 2. Koszty pobytu osoby z niepełnosprawnością

w Domu Pomocy Społecznej oraz mieszkaniu wspomaganym (dane za 2016 r.)

\begin{tabular}{|c|c|c|}
\hline & $\begin{array}{c}\text { Średni miesięczny całkowity koszt } \\
\text { pobytu w DPS: } 3.200 \mathrm{zf}\end{array}$ & $\begin{array}{l}\text { Średni miesięczny koszt w przypad- } \\
\text { ku mieszkania wspomaganego dla } \\
\text { osoby z niepełnosprawnością inte- } \\
\text { lektualną: } 1.736,24 \mathrm{zt}\end{array}$ \\
\hline Miasto & $\begin{array}{l}1.887 \text { zł (średni koszt miesięczny na } \\
\text { jedną osobę) }\end{array}$ & $\begin{array}{l}\text { 799,61 zł (koszt asystentów - opie- } \\
\text { kunów, koszt specjalistycznych } \\
\text { usług opiekuńczych, koszt różnicy } \\
\text { w czynszu, koszt dodatku miesz- } \\
\text { kaniowego oraz obniżki czynszu) }\end{array}$ \\
\hline Mieszkaniec & $\begin{array}{l}1.313 \text { zł (średni koszt miesięczny } \\
\text { ponoszony przez mieszkańca DPS } \\
\text { /jego rodzinę) }\end{array}$ & $\begin{array}{l}210,53 \text { zł (czynsz, nie wliczono } \\
\text { kosztów wyżywienia) }\end{array}$ \\
\hline $\begin{array}{l}\text { Organizacja } \\
\text { pozarządowa } \\
\text { PSONI }\end{array}$ & & $\begin{array}{l}726,10 \text { zł (środki z PFRON, z PUP } \\
\text { i własne) }\end{array}$ \\
\hline
\end{tabular}

Źródło: Opracowanie własne na podstawie A. KMIEĆ-LUCIUK, Mieszkania wspomagane, 2018.

\footnotetext{
${ }^{22}$ M. AnAsz, K. Mrugalska, J. WojtyŃSKA, M. Ferenc, Życie w integracji. Stargardzki model lokalnego systemu rehabilitacji i wsparcia społeczno-zawodowego osób z niepetnosprawnościa intelektualna, Wydawnictwo PFON, Warszawa 2014, s. 108.

${ }^{23}$ A. KMIEĆ-LUCIUK, Mieszkania wspomagane w polityce mieszkaniowej i społecznej Stargardu. Program „Potrzebny dom”, http://www.tbs.stargard.pl/ pliki/aa-dopu/1_mieszkania_ws pomagane-_w-polityce-mieszkaniowej-i-spolecznej-stargardu_agata_kmiec_luciuk.pdf (dostęp 28.04.2018).
} 
Średnio koszt pobytu w mieszkaniu wspomaganym jest niższy o 45,7\% od kwoty, którą ponosi gmina oraz bliscy osoby za pobyt w DPS. Korzyści finansowe w przypadku mieszkań uzyskuje miasto, którego koszty na osobę są niższe o $57,7 \%$, mieszkaniec, którego koszty są niższe średnio o $84 \%$.

Podstawową korzyścią mieszkań wspomaganych w Stargardzie jest ich umieszczenie w społeczności lokalnej, co stanowi modelowe rozwiązanie zgodne $\mathrm{z}$ art. 19 KoPON, gdyż osobom z niepełnosprawnością oferowane są usługi w miejscu zamieszkania, niezbędne do życia w społeczności lokalnej, umiejscowienie mieszkań zapobiega ich izolacji oraz segregacji społecznej.

\section{Mieszkania chronione w Płocku}

Zainspirowane modelem stargardzkim, władze Płocka również przy współpracy z TBS w listopadzie 2014 r. oddały do użytku 28 mieszkań chronionych, w tym 13 mieszkań dla osób z niepełnosprawnością (pozostałe dla osób starszych, wychodzących z przemocy w rodzinie, opuszczających pieczę zastępczą i ośrodki opiekuńczo-wychowawcze, a także dla bezdomnych). Zaoferowanie 28 mieszkań chronionych w budynku przy ul. Kutrzeby jest próbą nawiązania do idei mieszkalnictwa mieszanego, gdzie zamieszkują obok siebie seniorzy, osoby z niepełnosprawnością, osoby młode. Taki układ - zdaniem Cezarego Dusio - zastępcy dyrektora MOPS ,_...] daje dodatkową wartość, gdyż osoby w nich przebywające będą mogły nawzajem sobie pomagać i się wspierać $[\ldots]$ jedno z mieszkań będą zajmować trzy starsze panie, emerytowane nauczycielki, którym z pewnością przyda się pomoc osób młodych (wychowanków pieczy zastępczej), którzy potrzebują ciepła i życzliwości"24.

Mieszkania chronione powstały dzięki współpracy Miejskiego Towarzystwa Budownictwa Społecznego (MTBS) oraz MOPS-u, projekt był innowacyjny na skalę kraju. Inwestorem było miasto, które skorzystało ze wsparcia finansowego Banku Gospodarstwa Krajowego. Mieszkania składają się z 1 lub 2 pokoi, kuchni, przedpokoju, WC oraz wyposażone są w instalację wodno-kanalizacyjną, elektryczną, centralne ogrzewanie. Jeden z lokali jest w pełni przystosowany dla potrzeb osób z niepełnosprawnością ruchową. Mieszkania zostały wykończone w bardzo wysokim standardzie i częściowo umeblowane przez MOPS. W 2017 r. w mieszkaniach chronionych przebywały 23 osoby $\mathrm{z}$ niepełnosprawnością ${ }^{25}$. Pobyt $\mathrm{w}$ mieszkaniach ma na celu wzmocnienie

\footnotetext{
24 http://www.plock.eu/pl/aktualnosci/details/article,6105,1,1.html (dostęp 29.08.2018).

${ }^{25}$ Ocena zasobów pomocy społecznej miasta Płocka za 2017 rok, kwiecień, Płock 2018, s. 7-8 oraz Sprawozdanie z działalności Miejskiego Ośrodka Pomocy Społecznej w Płocku za 2017 rok, kwiecień, Płock 2018, s. 20.
} 
umiejętności funkcjonowania osób w środowisku oraz społeczności lokalnej. Pobyt przyznawany jest decyzją administracyjną, poprzedzoną wywiadem środowiskowym, dokonaniem uzgodnień i stworzeniem indywidualnego programu usamodzielniania lub wsparcia. Co trzy miesiące dokonywana jest ocena sytuacji mieszkańca. Pobyt w mieszkaniach jest odpłatny, zaś jego wysokość jest ustalana na podstawie decyzji administracyjnej wydanej przez Dyrektora MOPS- $\mathrm{u}^{26}$.

Niestety w budynku, zbudowanym przez TBS, na mieszkania chronione przeznaczone zostały dwie klatki, w trzeciej klatce znajdują się mieszkania komunalne, w opinii autora takie rozwiązanie ma charakter segregacyjny, gdyż brakuje wymieszania mieszkań chronionych z mieszkaniami dla pozostałych mieszkańców budynku, zaś zaproponowany przez władze MOPS model nie odzwierciedla założeń art. 19 KoPON. Niemniej jednak przywołany przykład może być inspiracją dla innych gmin oraz TBS-ów planujących inwestowanie w mieszkalnictwo wspomagane.

\section{Mieszkanie chronione przy Domu Pomocy Społecznej w Konarach}

Przykładem dobrej praktyki w procesie deinstytucjonalizacji jest mieszkanie chronione-treningowe, funkcjonujące przy Domu Pomocy Społecznej, prowadzonym przez Bonifraterską Fundację Dobroczynną. Mieszkanie powstało w ramach projektu finansowanego ze Szwajcarsko-Polskiego Programu Współpracy. Mieszkanie jest przeznaczone dla osób z niepełnosprawnościa intelektualną i chorujących psychicznie, a pobyt w nim ma na celu usprawnienie i usamodzielnienie mieszkańców (w zakresie podstawowych czynności życiowych, samodzielnego gospodarowania i zarządzania budżetem, kontaktów społecznych oraz aktywizacji zawodowej).

Mieszkanie powstało w wolno stojącym budynku, ogrodzonym, ulokowanym w sąsiedztwie DPS, dzięki czemu jest mieszkaniem niezależnym, funkcjonującym poza ,instytucją". Składa się z trzech pokoi 1-osobowych (umeblowanych) oraz przestrzeni wspólnej: salonu (z telewizorem, DVD oraz

\footnotetext{
${ }^{26}$ Zgodnie z uchwałą Rady Miasta Płocka nr 83/VI/2015 z dnia 31 marca 2015 r. w sprawie: ustalenia szczegółowych zasad ponoszenia odpłatności za pobyt w mieszkaniach chronionych. Podstawą do ustalenia miesięcznej odpłatności za pobyt w mieszkaniu chronionym jest kwota średniego miesięcznego kosztu utrzymania mieszkania chronionego, która obejmuje zużycie wody, energii elektrycznej, energii cieplnej, gazu, odprowadzenie ścieków, wywóz nieczystości oraz czynsz. Zaś ostateczna wysokość odpłatności za pobyt w mieszkaniu chronionym jest indywidualnie uzgadniana $\mathrm{z}$ osobą ubiegającą się o skierowanie przy uwzględnieniu kosztów związanych $\mathrm{z}$ utrzymaniem danego mieszkania chronionego oraz w zależności od oceny sytuacji materialnej osoby skierowanej do pobytu w mieszkaniu chronionym.
} 
wieżą stereo) z aneksem kuchennym (kuchenka, lodówka, kuchenka mikrofalowa, czajnik), przedpokoju oraz łazienki (z pralką). Ponadto w mieszkaniu znajduje się komputer $\mathrm{z}$ dostępem do Internetu ${ }^{27}$. Wyposażenie mieszkania warunkowane było celem zamieszkania w lokalu, którym jest usamodzielnienie się jego mieszkańców w zakresie codziennych czynności (takich jak gotowanie, pranie, sprzątanie), stąd za konieczne uznano wyposażenie lokalu w sprzęt umożliwiający uczenie się tych umiejętności. Podkreślić należy, iż intencją twórców lokalu było stworzenie miejsca nieodbiegającego standardem od „przeciętnych” mieszkań. Ponadto mieszkańcy mogą korzystać z ogólnodostępnych pomieszczeń DPS, takich jak: kaplica, sala spotkań/świetlica, sala terapii zajęciowej, sala rehabilitacji czy sala terapii sensorycznej ${ }^{28}$. Terapia usamodzielniająca obejmuje: trening ekonomiczny (zarządzania własnym budżetem, decyzji zakupowych itd.), higieniczny, prowadzenia gospodarstwa domowego oraz kompetencji społecznych. Terapia świadczona jest przez opiekuna-koordynatora ( 2 razy po 2 godz. tygodniowo), pracownika socjalnego (2 godz. tygodniowo) oraz psychologa (2 godz. tygodniowo) - wszyscy są pracownikami DPS. Pobyt w mieszkaniu chronionym trwa od 6 miesięcy do $1 \mathrm{roku}^{29}$.

Mieszkańcy to mężczyźni, będący uczestnikami Warsztatu Terapii Zajęciowej, Środowiskowego Domu Samopomocy lub Zakładu Aktywizacji Zawodowej prowadzonych przez Fundację. Odpłatność za mieszkanie wynosi 600 zł, z czego mieszkaniec płaci 250 zł, zaś resztę - 350 zł dopłaca Bonifraterska Fundacja Dobroczynna. Problemem jest brak mieszkańców spoza podopiecznych Fundacji, co świadczy o braku świadomości o istnieniu takiej formy wsparcia wśród lokalnych OPS-ów, władz, osób z niepełnosprawnością oraz ich rodzin, stąd brak podopiecznych z zewnątrz, skierowanych przez OPS-y ${ }^{30}$.

Podkreślić należy, iż w ramach Szwajcarsko-Polskiego Programu Współpracy w woj. świętokrzyskim również powstały mieszkania chronione (okre-

${ }^{27}$ J. KrzYszKowsKi, A. ŁUKOMSKA-DulaJ, A. MiśKowIEC i in., Utworzenie i funkcjonowanie modelowego przyktadu, s. 108-109.

${ }^{28}$ http://www.sppw.rops.krakow.pl/2016/06/27/6118/ (dostęp 12.09.2018) oraz J. KRZYSZKOWSKI, A. ŁUKOMSKA-DULAJ, A. MIŚKOWIEC i in., Utworzenie i funkcjonowanie modelowego przyktadu, s. 110.

${ }^{29}$ B. GRZANKOwSKI, Bezpieczne mieszkanie w podkrakowskich Konarach, czyli jak pomóc niepetnosprawnym zyskać niezależność, 26.02.2016,http://www.radiokrakow.pl/wiadomosci/kra kow/bezpieczne-mieszkanie-w-podkrakowskich-konarach-czyli-jak-pomoc-niepelnosprawnymzyskac-niezaleznosc/ (dostęp 12.09.2018).

${ }^{30}$ J. KRZYSZKowsKi, A. ŁUKOMSKA-DULAJ, A. MiśKOwIEC i in., Utworzenie i funkcjonowanie modelowego przyktadu, s. 112-113. 
ślane też lokalami aktywizacyjnymi). W funkcjonujących DPS-ach poprzez dobudowę bądź remont skrzydła dotychczasowego budynku DPS-u ${ }^{31}$. W opinii autora takie rozwiązanie uniemożliwia wyjście z ,instytucji”, gdyż ulokowanie lokali w budynku przeczy idei życia w społeczności lokalnej. Zaletą takiego rozwiązania jest możliwość korzystania z infrastruktury DPS (sal rehabilitacyjnych, terapeutów), nie bez znaczenia jest również znaczące obniżenie kosztów opieki. Należy jednak zadać pytanie czy korzyści ekonomiczne winny przesłaniać korzyści społeczne?

\section{MIESZKALNICTWO WSPOMAGANE MIESZANE - WŁĄCZENIE W SPOŁECZNOŚĆ LOKALNĄ WE FRANCJI}

W ramach dobrych praktyk w zakresie mieszkań wspomaganych, promujących funkcjonowanie osób z niepełnosprawnością w społeczności lokalnej, zaprezentowane zostną dwa przykłady tzw. mieszkalnictwa wspomaganego mieszanego: Projet de l'Ilot Bon Secourss oraz Projet de la résidence REVIS.

Projet de l'Ilot Bon Secours ${ }^{32}$ jest przykładem dobrej praktyki w zakresie mieszkalnictwa mieszanego, realizowany od 2011 r. w mieście Arras. W budynku, spośród 69 mieszkań dwu-, trzypokojowych, $60 \%$ mieszkań zamieszkują osoby starsze. Jak wynika z dotychczasowych doświadczeń - seniorzy organizują swoje życie i wzajemnie sobie pomagają zgodnie z zasadą empowermentu. Z kolei w 10 mieszkaniach - dla osób z niepełnosprawnością - mieszkają osoby z zespołem Downa, zamieszkanie w mieszkaniach mieszanych wpłynęło na ich aktywność - podjęły zatrudnienie już po zamieszkaniu), w pozostałych mieszkają młode rodziny. Współżycie mieszkańców opiera się na wzajemnym szacunku, wspólnotowym funkcjonowaniu opartym na wzajemnej mobilizacji. Mieszkańcy aktywizują się: wspólnie dbając o ogród, organizując wspólne warsztaty, przedszkole oraz prowadząc animację imprez

\footnotetext{
${ }^{31}$ W ramach Szwajcarsko-Polskiego Programu Współpracy powstały w woj. świętokrzyskim przy DPS-ie w Kielcach lokale aktywizujące dla osób z niepełnosprawnością oraz starszych, w tym celu wyremontowano skrzydło DPS, gdzie na trzecim piętrze budynku powstało 20 lokali aktywizujących dla 30 osób starszych i niepełnosprawnych, które są w stanie funkcjonować samodzielnie, zob. szerzej https://dpsjp2.pl/lokale-aktywizujace/ (dostęp 11.09.2018) oraz J. KRZYSZKowski, A. ŁUKOMSKA-DulaJ, A. MiśKowIEC i in., Utworzenie i funkcjonowanie modelowego przyktadu, s. 70-75.

32 l'Ilot Bon Secours w thumaczeniu: wyspa dobrej pomocy.
} 
kulturalnych (teatr, biblioteka, przegląd filmowy) ${ }^{33}$. Niestety wadą jest koszt budowy budynku - $22 \mathrm{mln}$ euro.

Projet de la résidence REVIS ${ }^{34}$ jest projektem realizowanym wspólnie od 2012 r. przez władze miasta Lille, Gminny Ośrodek Pomocy Społecznej w Lille, partnerów społecznych - organizacje działające na rzecz osób starszych oraz osób z niepełnosprawnością ${ }^{35}$ oraz Sia Habitat. Budowa budynku trwa od 2016 r., równolegle strony zaangażowane w projekt prowadziły konsultacje, aby ta koncepcja miała „włączeniowy” charakter dla wszystkich mieszkańców. Ten projekt składa się z kompleksu mieszkalnego o charakterze mieszanym, w budynku zaplanowano 74 mieszkania (od 1- do 4-pokojowych) dla rodzin z dziećmi lub bez, osób starszych, osób z niepełnoprawnością ruchową (70\% mieszkań dostosowanych jest do osób z niepełnosprawnością ruchową) oraz niepełnosprawnością intelektualną ${ }^{36}$. Nowym pomysłem zgodnie z założeniami władz lokalnych oraz miejscowego ośrodka pomocy społecznej - było przeznaczenie parteru budynku na działalność zawodową ${ }^{37}$, w której zatrudnienie miały znaleźć osoby z niepełnosprawnością, co wskazywało na kompleksową integrację społeczno-zawodową tychże osób w środowisku lokalnym. W projekcie w ramach działań aktywizacyjnych o charakterze integracyjnym przewidywane jest także realizowanie wspólnych zajęć w sali $50 \mathrm{~m}^{2}$ oraz na świeżym powietrzu - we wspólnym ogrodzie przez mieszkańców. Ponadto do wykorzystania jest przestrzeń $218 \mathrm{~m}^{2}$ na parterze, od strony ulicy, przeznaczona na najem dla działalności usługowej

\footnotetext{
${ }^{33}$ Zob. szerzej: http://www.cerdd.org/Parcours-thematiques/Territoires-durables/Initiativesdu-parcours-7/L-ilot-Bon-Secours-de-Pas-de-Calais-Habitat-a-Arras (dostęp 10.05.2018).

${ }^{34}$ REVIS - Résidence Intergénérationnelle de Vie Eco-citoyenne Solidaire. Nazwa określa cele projektu - solidarność społeczną oraz międzygeneracyjną mieszkańców.

${ }^{35}$ APF - Association des Paralysés de France (Stowarzyszenie na Rzecz Osób Dotkniętych Paraliżem), Générations et Culture oraz Humanis - organizacje działające na rzecz osób starszych.

${ }^{36}$ Habitat et handicap. Recommandations pour promouvoir un habitat dans une société inclusive, Association des Paralysés de France, Pour La Solidarité-PLS, Université Paris Est Créteil, Paris 2014, s. 36.

${ }^{37} \mathrm{~W}$ trakcie realizacji projektu okazało się, że nie jest możliwe sfinansowanie tworzenia miejsc pracy dostosowanych do potrzeb osób z niepełnosprawnością, miejsca te powstaną poza projektem. Zob. 7ème Printemps de l'Intergénération. Intergénération, Habitat et Initiatives Solidaires 27 bonnes pratiques - 4 outils, Générations et Cultures, l'Union des Centres sociaux et socioculturels des Hauts de France, l'Union des CCAS du Nord, Arras 2018, s. 60. https:// www.generationsetcultures.fr/wp-content/uploads/2018/03/generations-et-cultures-VD.pdf (dostęp 13.09.2018).
} 
o charakterze społecznym. Pierwsze mieszkania miały być oddane jesienią 2018 r., zaś na początku 2019 r. oddana zostanie wspólna przestrzeń dla mieszkańców. Koszt inwestycji oszacowano na niespełna 9,5 mln euro. $\mathrm{Na}$ chwilę obecną trudno przewidzieć jak będzie wyglądała integracja pomiędzy mieszkańcami mieszkań, czas pokaże czy zostanie powtórzony sukces z Arras.

Na podstawie przedstawionych powyżej analiz oraz przykładów dobrych praktyk możliwe jest sformułowanie następujących wniosków oraz rekomendacji:

- konieczne jest opracowanie narodowego planu deinstytucjonalizacji lub uwzględnienie działań w Strategii na rzecz Osób Niepełnosprawnych 20182030, a także wprowadzenie zmian systemowych związanych z funkcjonowaniem mieszkań wspomaganych jako alternatywy dla mieszkań chronionych;

- stworzenie rozwiązań prawno-organizacyjnych określających warunki tworzenia oraz finansowania mieszkalnictwa wspomaganego - pozwoli NGO's, prowadzącym mieszkania na zlecenie samorządu zaprzestać funkcjonowania od projektu do projektu (PFRON, UE) w zakresie finansowania kosztów oferowanych w mieszkaniach usług;

- mieszkania wspomagane - nie są rozwiązaniem dla wszystkich osób z niepełnosprawnością, przykładem małe domy dla osób z autyzmem;

- usytuowanie mieszkań powinno spełniać przesłanki art. 19 KoPON, co widoczne jest w przykładach ze Stargardu (jako realnej alternatywy dla DPS) oraz częściowo z Płocka;

- przykładem udanej deinstytucjonalizacji opieki jest mieszkanie chronione przy DPS w Konarach, a z drugiej strony przykłady lokali aktywizujących przy DPS-ach, np. w Kielcach, wskazuja przede wszystkim na ekonomiczne przesłanki deinstytucjonalizacji, nieuwzględniające innych korzyści - społecznych, związanych z funkcjonowaniem w społeczności lokalnej;

- czerpiąc z doświadczeń francuskich podkreślić należy, iż budowa mieszkań mieszanych skutecznie zapobiega segregacji poprzez brak osobnego budynku, lokalizacja budynków z mieszkaniami mieszanymi, zgodnie z art. 19 KoPON, umożliwia w pełni funkcjonowanie w społeczności lokalnej. Wartością dodaną jest także wzajemna aktywizacja mieszkańców oraz ich upodmiotowienie, niemniej jednak z uwagi na koszty, przykłady z Francji jawią się jako „szklane domy”. W opinii autora budowa mieszkań wspomaganych w Polsce może być realizowana w oparciu o ponad 300 TBS-ów, przy wykorzystaniu idei mieszkań wspomaganych mieszanych. 


\section{BIBLIOGRAFIA}

7ème Printemps de l'Intergénération. Intergénération, Habitat et Initiatives Solidaires 27 bonnes pratiques -4 outils, Générations et Cultures, l'Union des Centres sociaux et socioculturels des Hauts de France, l'Union des CCAS du Nord, Arras 2018.

Aktualizacja Społecznego Raportu Alternatywnego z realizacji Konwencji o prawach osób z niepełnosprawnościami w Polsce, http://konwencja.org/ download/aktualizacja-spolecznego-raportu-alternatywnego-pdf/\#

Anasz M., MrugalsKa K., WoJTyńsKa J., Ferenc M., Życie w integracji. Stargardzki model lokalnego systemu rehabilitacji i wsparcia społeczno-zawodowego osób z niepełnosprawnością intelektualną, Wydawnictwo PFON, Warszawa 2014.

DĄBEK M., „Za życiem” pod lupą: komu mieszkania chronione? http://www.niepelnosprawni. $\mathrm{pl} /$ ledge/x/576278

DuDZIŃSKA A., SoBCZAK A., Potrzeby i oczekiwania osób z różnymi niepełnosprawnościami dotyczące przyszłej sytuacji mieszkaniowej, w: Niezależne życie i pełne uczestnictwo osób niepełnosprawnych w życiu społecznym, red. A. Sobczak, Wydawnictwo Uniwersytetu Łódzkiego, Łódź 2012.

DUDZIŃSKA A., Zestawienie głównych różnic między projektowanymi rozwiązaniami z rządowego projektu nowelizacji ustawy o pomocy społecznej w zakresie art. 53 (nr 212 z wykazu prac Rady Ministrów) a obecnymi przepisami, http://cbnn.pl/wp-content/uploads/2017/ 06/Zestawienie-różnic-art.-53-w-związku-z-Za-życiem.pdf

From institutions to community living, Part I: Commitments and structures, European Union Agency for Fundamental Rights, Luksemburg 2017.

GrzANKowsKi B., Bezpieczne mieszkanie w podkrakowskich Konarach, czyli jak pomóc niepełnosprawnym zyskać niezależność, http://www.radiokrakow.pl/ wiadomosci/kra kow/be zpieczne-mieszkanie-w-podkrakowskich-konarach-czyli-jak-pomoc-niepelnosprawnym-zysk ac-niezaleznosc

Habitat et handicap. Recommandations pour promouvoir un habitat dans une société inclusive, 2014, Association des Paralysés de France, Pour La Solidarité-PLS, Université Paris Est Créteil, Paris.

KMIEĆ-LUCIUK A., Mieszkania wspomagane w polityce mieszkaniowej i społecznej Stargardu. Program „Potrzebny dom”, Stargard 2018, http://www.tbs.stargard.pl/pliki/aa-dopu/1_miesz kania_wspomagane-_w-polityce-mieszkaniowej-i-spolecznej-stargardu_aga ta_kmiec_luciu k.pdf

Krzyszkowski J., Łukomska-Dulaj A., MiśKowiec A., Rogalska E., Sochacka M., Utworzenie i funkcjonowanie modelowego przykładu mieszkania chronionego oraz lokalu aktywizującego, Ministerstwo Zdrowia, Warszawa 2017.

MARCINIAK-MADEJSKA N., Mieszkalnictwo wspomagane dla osób z niepełnosprawnością intelektualną, „Niepełnosprawność i Rehabilitacja” 1(2014).

MarciniaK-Madejska N., StenKa R., Weiner K., Rozwiązywanie problemu bezdomności i wykluczenia mieszkaniowego w oparciu o usługi świadczone w lokalnej społeczności, ROPS Poznań 2015.

Modernizacja pieczy społecznej: Wykorzystanie środków unijnych w zakresie przejścia od opieki instytucjonalnej do opieki świadczonej na poziomie lokalnym. Dobre praktyki, Rzecznik Praw Obywatelskich, Warszawa 2014.

NeCEL R., ZaręBA M., Usługi społeczne - między teorią a praktyką działań pomocowych, „Praca Socjalna” 1(2017).

PASZKOwICZ M.A. (red.), Ćwierć wieku systemu rehabilitacji społecznej i zawodowej osób z niepełnosprawnościami w Polsce - wybrane aspekty, w: Osoby z niepełnosprawnościami 
w polityce społecznej, t. 2: 25-lecie systemu rehabilitacji zawodowej i społecznej w Polsce, Wydawnictwo Uniwersytetu Zielonogórskiego, Zielona Góra 2017.

PoDGóRSKA-JACHNIK D., Praca socjalna z osobami z niepełnosprawnością i ich rodzinami, Centrum Rozwoju Zasobów Ludzkich, Warszawa 2014.

Realizacja przez Polskę zobowiązań wynikających z Konwencji o prawach osób niepełnosprawnych. Sprawozdanie Rzecznika Praw Obywatelskich, Biuro Rzecznika Praw Obywatelskich, Warszawa 2015, https://www.rpo.gov.pl/sites/ default/files/Sprawozdanie\%20KPON\% 2020 15.pdf

Rozporządzenie Ministra Rodziny, Pracy i Polityki Społecznej z dnia 26 kwietnia 2018 r. w sprawie mieszkań chronionych, Dz. U. 2018 r., poz. 822.

Społeczny Raport Alternatywny z realizacji Konwencji o prawach osób z niepełnosprawnościami w Polsce, Warszawa 2015, http://konwencja.org/ download/spoleczny-raport-alternatyw ny-doc/\#

Sprawozdanie z działalności Miejskiego Ośrodka Pomocy Społecznej w Płocku za 2017 rok, kwiecień, Płock 2018.

Strategia na rzecz Odpowiedzialnego Rozwoju, Ministerstwo Rozwoju, Warszawa 2017.

Ustawa o pomocy społecznej z dnia 12 marca 2004 r., Dz.U. z 2017 r. poz. 1769, 1985, z 2018 r. poz. $650,700$.

Ustawa z dnia 22 czerwca 2017 r. o zmianie niektórych ustaw w związku z realizacją programu „Za życiem”, Dz.U. 2017 r., poz. 1292.

Wytyczne w zakresie realizacji przedsięwzięć w obszarze włączenia społecznego i zwalczania ubóstwa z wykorzystaniem środków Europejskiego Funduszu Społecznego i Europejskiego Funduszu Rozwoju Regionalnego na lata 2014-2020, Ministerstwo Finansów i Rozwoju, Warszawa 2014.

\section{MIESZKANIA WSPOMAGANE DLA OSÓB Z NIEPEŁNOSPRAWNOŚCIA W PROCESIE DEISTYTUCJONALIZACJI}

\section{S t r e s z c z e n i e}

Celem niniejszego artykułu jest przedstawienie roli mieszkań wspomaganych w procesie deinstytucjonalizacji. W analizie odwołano się do dokumentów międzynarodowych oraz krajowych, a także przykładów dobrych praktyk w tworzeniu i prowadzeniu mieszkań wspomaganych dla osób z niepełnosprawnością. Autor w zakończeniu przedstawił rekomendacje i wnioski dotyczące mieszkań wspomaganych.

Słowa kluczowe: osoby z niepełnosprawnością; mieszkania wspomagane; deinstytucjonalizacja; usługi społeczne. 